\title{
ENTREPRENEURIAL ORIENTATION AND ORGANIZATIONAL PERFORMANCE OF E-BUSINESS IN MALAYSIA: THE MODERATING ROLE OF EXTERNAL ENVIRONMENT
}

\author{
Sabrinah Adam ${ }^{1}$ \\ Azman Hashim International Business School, Universiti Teknologi Malaysia (UTM), Malaysia. \\ (Email: sabrinah@utm.my) \\ Mohd Khairuddin Ramliy ${ }^{2}$ \\ Azman Hashim International Business School, Universiti Teknologi Malaysia (UTM), Malaysia. \\ (Email: mohdkhairuddin@utm.my) \\ Thoo Ai Chin ${ }^{3}$ \\ Azman Hashim International Business School, Universiti Teknologi Malaysia (UTM), Malaysia. \\ (Email: acthoo@utm.my) \\ Adaviah Mas'od ${ }^{4}$ \\ Azman Hashim International Business School, Universiti Teknologi Malaysia (UTM), Malaysia. \\ (Email: adaviah@utm.my) \\ Farrah Merlinda Muharam ${ }^{5}$ \\ Azman Hashim International Business School, Universiti Teknologi Malaysia (UTM), Malaysia. \\ (Email: merlinda@utm.my)
}

Received date: 10-09-2019

Revised date: 11-09-2019

Accepted date: 30-09-2019

Published date: 15-10-2019

To cite this document: Adam, S., Ramliy, M. K., Thoo, A. C., Mas'od, A., \& Muharam, F. M. (2019). Advanced International Journal of Business, Entrepreneurship and SMEs, 1 (1), 01-17. DOI: 10.35631/aijbes.11001

Abstract: There has been relatively little research that examines the relationship between the external environment and their consequences on the organizational performance of e-business in developing countries. This research represents an attempt to do so from the Malaysian ebusiness perspectives. This research examines the relationships between entrepreneurial orientation and organizational performance and on the role of the external environment as a moderator between the relationships. The consideration of putting moderator factors in this research allows more precise descriptions of the relationship between the two variables mentioned and the outcome of the research. This study was grounded by Resource-Based View theory as the underlying basis. This study adopted a quantitative approach where 400 questionnaires were distributed to the target population and 381 were returned. Structural Equation Modelling was performed on the quantitative data using SMART PLS 3.0. The quantitative findings indicated that entrepreneurial orientation variables of innovativeness, proactiveness, risk-taking, competitive aggressiveness and autonomy have significant effects on financial and non-financial organizational performance. However, the moderating effect of 
the external environment on the relationship was found not significant. This study concluded that entrepreneurial orientation and the external environment are vital to promoting the organizational performance of e-business in Malaysia. These findings able to serve as a guideline for e-business owners or founders to improve their organizational performance thus compete in the digital sphere.

Keywords: Entrepreneurial Orientation, External Environment, Organizational Performance, E-Business

\section{Introduction}

Entrepreneurs have the crucial role of managing the decision making process in their firm to ensure it is effective. Entrepreneurial orientation (EO) plays an important part in this process. EO, which is a key concept of entrepreneurship and has received keen scholarly attention, is an organizational level entrepreneurial activity (Covin \& Slevin, 1991; Rauch et al., 2009; Covin \& Lumpkin, 2011). Furthermore, EO refers to the strategy making process that provides organizations with the basis for entrepreneurial decisions and actions (Lumpkin \& Dess, 1996). EO is a key ingredient for organizational success (Lumpkin \& Dess, 1996) and has been found to lead firms towards achieving higher performance (Zahra \& Covin, 1995; Wiklund \& Shepherd, 2003). Dess, Lumpkin and Covin (1997) suggested that organizations with an EO are more likely to perform better than those that lack such an orientation. This shows the importance of EO in a business, including e-business.

E-business is perceived as a strategy that directs business processes across organizational boundaries successfully (Khamis, Sulaiman, \& Mohezar, 2014). As indicated by Basu and Muylle (2007), e-business has significantly changed the way business processes are planned, executed and upgraded, adjusting industry structures and shifting the balance of power between corporations and their suppliers and customers (Chang and Dasgupta, 2015). Since the independence achievement in 1957, Malaysia has experienced rapid economic and social development, especially in the previous three decades. From then on, the Malaysian government has made a great strides in digital development and inclusion in its journey to accomplish developed nation status by 2020 .

Despite strong economic growth in recent times, the external environment remains a key challenge to Malaysia to keep up a positive development in near-term. Understanding the environment within which the business has to operate is very important for running a business unit successfully at in any place. Likewise, as indicated by Ahmad, Rani, and Kassim (2010), the current business environment in Malaysia is getting more competitive. In order for firms to stay competitive in the marketplace domestically and internationally, organizations have dependably strived to enhance themselves by making better approaches to address their customers' needs.

A sound environment for business can give that organization an edge over and above other organizations and help it to achieve a competitive advantage. However, a careful scanning of business environment can provide a particular firm with the knowledge of how to deal with the issues involved in the area in which it operates (Aliyu \& Mahmood, 2015). In making a decision on whether or not to invest in e-business and the issue of whether decision making influenced business performance have always been asked. EO was proven to be a useful construct that able to maintain their performance trajectories while other firms are not (Covin and Lumpkin, 2011). In today's competitive environment, companies are forced to behave in an 
entrepreneurial way in order to try to survive in the market. These pressures force companies to look for best practices and new ways to stay ahead or to keep up with competition in the future.

Previous studies have investigated the relationship between EO and business performance moderated by external environment in a variety of contexts, including small and medium enterprises (SMEs) (Jabeen \& Mahmood, 2014; Jabeen, Aliyu, \& Mahmood, 2016), manufacturing firms (Murgor Paul Kimutai, 2014; Alkali \& Isa, 2012;Wang \& Huynh, 2013), and small and medium enterprises (SMEs) (Madhoushi, Sadati, \& Delavari, 2011; Aliyu, Rogo, \& Mahmood, 2015). However, few attempts to date have been made to investigate how EE effect EO and organizational performance in the context of the e-business in Malaysia. Therefore, the current study attempts to fills this void by examining the relationship between the EO, EE and organizational performance of e-business.

Given the gaps in the literature on the subject matter, the present study serves as groundwork to investigate the role of EE as moderator in the relationship between EO and organizational performance using the theory of RBV of e-business in Malaysia. EE is incorporated into the research model to assess its moderating effect on the relationships under this study. The following section will discuss on the links between EO and organizational performance and the role of EE as a moderater in the EO and organizational performance relationship are hypothesized in the following section. Next section, followed by a brief discussion of the reseach methods and data analysis. This paper concludes with a discussion of the findings of the present study.

\section{Literature Review and Hypotheses Development}

\section{Entrepreneurial Orientation and Organizational Performance}

EO is an important competency in becoming an entrepreneur and managing a firm's performance. The role of the EO is crucial due to its positive influence a firm's business performance (Covin \& Slevin, 1989; Lumpkin \& Dess, 1996). Firms with high levels of EO tend to constantly scan and monitor the activities of entrepreneurship in order to find new opportunities and strengthen their competitive positions (Covin \& Miles 1999).

A study by Deepababu \& Manalel (2016) stated that the importance of EO and its influence on organizational performance have been highlighted in both conceptual and empirical view points (Covin \& Slevin, 1991; Lumpkin \& Dess, 1996) and there are many empirical research (Lumpkin \& Dess, 2001; Wiklund \& Shepherd, 2003; Wiklund \& Shepherd, 2005) which are concerned with the positive implications that EO has on organizational performance (Lumpkin \& Dess, 1996; Wiklund, 1999). At the empirical level, past studies have shown a positive relationship between EO and firm performance (Lee \& Pennings, 2001; Wiklund, 1999; Wiklund \& Shepherd, 2005). Several studies have revealed a positive impact of EO on performance (Alegre \& Chiva, 2013; Hakala, 2013). Thus, it may be beneficial to adopt an EO, because entrepreneurial strategies are regarded as being related to better firm performance and because of that the relationship between EO and firm performance has been at the forefront of entrepreneurship literature for many years (Deepababu \& Manalel, 2016). Based on the above discussion, the following hypothesis are formulated:

\section{$H_{1}$. Entrepreneurial orientation (EO) is positively related to organizational performance.}




\section{The Role of External Environment in the Entrepreneurial Orientation and Organizational Performance Relationship}

The external environment has been described as those factors and situations that are capable of dictating and influencing the performance of firms (Mohd, 2005). In this study, EE denoted forces outside the organization that exert uncontrollable influences on business activities and performance. The forces included price competition, technology or innovation, competitive strength, action of competitor, demand and consumer taste, outdated product, marketing practices, and safety. Besides, the study by Mohd (2005) stated that the external environmental factors are capable of determining the failure and success of the firms (Jabeen, Aliyu, \& Mahmood, 2016).

The relationship between EO and organizational performance has been widely studied by a number of researchers. However, some researchers, reported positive relationship, while others reported a negative relationship. Nonetheless, there are also scholars who found mixed results in the EO and organizational performance relationship. The studies which reported a positive and significant relationship between the two constructs include Wiklund and Shepherd (2003); Fairoz, Hirabuni and Tanaka (2010); Idar and Mahmood (2011); Al-Swidi and Mahmood (2012). However, some extents studies by Arbaugh, Cox \& Camp (2009) and Anderson (2010) reported a negative association between entrepreneurial orientation and business performance; whereas the study of Runyan, Droge and Swinney (2008) and Ambad and Abdul Wahab (2013) found mixed outcomes in the EO and organizational performance relationships. Hence, EO to performance relationship studies is inconclusive. However, Herath and Mahmood (2013) suggested the inclusion of moderator in strategic orientation to the business performance relationship.

Environmental effects on EO and the relationship between EO and performance have long been considered. Still, researchers continue to conduct studies designed to explore linkages between the environment and EO, or between EO and performance as affected by the environment (Covin \& Lumpkin, 2011). According to Jabeen \& Mahmood (2014) and Jaben, Aliyu and Mahmood (2016), it was contended that EO and firm performance relationship is dependent upon the EE. According to Martins and Rialp (2013) EE is always highlighted as a key contextual factor in the EO and organizational performance relationship. The main reason EE has been chosen as a variable in this study is because the significance of EE to e-business can be seen from the fact that no business operates in a vacuum, it must have an environment to operate in, for survival and to remain relevant. However, a careful scanning of business environment can provide a particular firm with the knowledge of how to deal with the issues involved in the area in which it operates (Aliyu \& Mahmood, 2015). Based on the above discussions, the following hypothesis is proposed:

\section{H2. The relationship between entrepreneurial orientation (EO) and organizational performance is moderated by the external environment (EE).}

\section{Extension of RBV using External Environment}

The Resource Based View (RBV) theory has become one of the most important theories in strategic management literature since 1990s (Chen, 2012). Essentially, the RBV is based on the assumptions that firms have heterogeneous resources and the resources remain imperfectly mobile over time (Thoo Ai Chin, 2014). RBV theory is very useful in enhancing the organization's competitive advantage through EO because they represent the aspects of the internal capability as an internal strength of the organization. 
In addition, this study focuses on on EE as a moderator is to enhance the EO and organizational performance relationship and also to contribute to the theory of resource based view (RBV) that suggests the existence of external environment along the EO and organizational performance relationship (Barney, 1991). Given the previously held belief that EE plays an important role where the changes and unpredictability in the EE in which firms operate determines how they fit and their ensuing performance..

With this, the researcher proposed the potential moderator role of EE to enhance the EO and organizational performance relationship and also contributes to the extended theory of resource based view (RBV) whereby the theory posits that RBV theory provides a powerful impact to an organization about how they can perform better than other organizations in the same market. The extended KBV in this study, require the e-business to be proactive and nurture an enabling business performance that facilitates EO and EE among employees in order to be relevant and sustainable in today's competitive market.

Figure 1 demonstrates the research model based on the proceeding discussion. Since past literature shows inconclusive results on $\mathrm{EO}$ and organizational performance, $\mathrm{EE}$ is adopted to assess its moderating effect on the postulated EO and organizational performance relationships in the present study. According to this model, entrepreneurial orientation is positively related to organizational performace $\left(\mathrm{H}_{1}\right)$ and it is conceptualized that external environment moderate the relationship between entrepreneurial orientation and organizational performance $\left(\mathrm{H}_{2}\right)$.

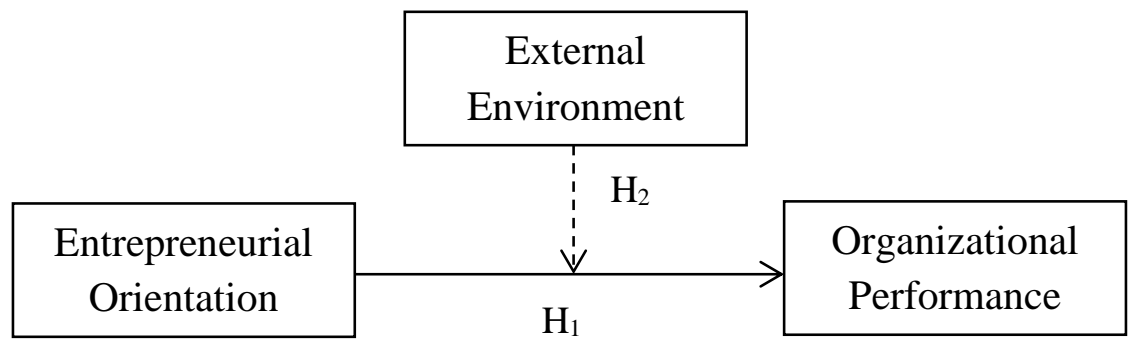

$$
\begin{array}{ll}
\text { Direct Effect } & \longrightarrow \\
\text { Moderating Effect } & -\cdots
\end{array}
$$

Figure 1: Research model

\section{Methodology}

The population of this study consists of all active e-business registered in Malaysia. The researcher drew the sample in Malaysia from the Companies Commission of Malaysia (CCM). Employing Krejcie and Morgan (1970) sampling table to determine minimum sample size to ensure adequate statistical capacity to investigate and explain the variables under investigation. A total of 381 active e-business in Malaysia are suggested based on the samling table and appropriate to assess the accessible population of the study.

A quantitative approach using self-administered questionnaire was adopted. All statements pertaining to entrepreneurial orientation, external environment and organizational performance were adopted and adapted from past literature (Bolton and Lane ,2012; Lumpkin and Dess, 2001; Lumpkin, Cogliser and Schneider, 2009; Naman \& Slevin, 1993; Lo, Wang, Wah \& Ramayah, 2016; Arshad, 2016). All key variables were measured by multiple statements, as this would afford greater degrees of freedom when partitioning the data into groups. It would 
also allow for adjustment of measurement error, thus increasing their reliability and predictive validity (Hair et al., 2014). Statements were also organized in sections without randomization based on the common objectives and contexts of the statements (Burns and Bush, 2005). A post hoc Harman single-factor analysis was also performed after data collection to ensure the variance in the data was not explained by one single factor, thus addressing the common method bias (Chang et al., 2010; Podsakoff et al., 2003). Except for demographic information, a five-point Likert scale where 1 indicating strongly disagree to 5 indicating strongly agree was adopted to measure the statements. Expert validation and pre-test was administered to secure face validity of the questionnaire in this study. Besides, pilot test was also conducted using the target respondents to finalize the usability of the questionnaire (Bryman \& Bell, 2011).

Stratified sampling technique was adopted to distribute questionnaire to the e-business in Malaysia. As such, three criteria were set to ensure the respondents, first must be the owner/founder of the e-business in Malaysia, second, must register under the Companies Commission of Malaysia (CCM), and third, the years of the establishment must be more than 1 year. In all, 400 copies were distributed, and 381 completed and usable copies were collected in a months time in November 2017, indicating that non-response bias was not a major issue. The data were then keyed in into SPSS and imported to SmartPLS to perform latent variable analysis (Ringle et al., 2015). The latter software utilizes structural equation modelling of partial least squares (PLS-SEM) approach to enhance predictive relevance by maximizing the variance of key target variables by different explanatory variables (Hair et al., 2014; Henseler et al., 2009).

\section{Findings}

\section{Normality Assumptions}

Table 1 reports the values of skewness and kurtosis normal ranged from -0.614 to 0.317 . At this stage, researcher confirmed the normality distribution criteria based on Skewness and Kurtosis, since the values are all below the benchmark value of \pm 3 (Tabachnick and Fidell, 2001), this suggests that all the observed variables collectively showed evidence of normality.

Table 1: Skewness and Kurtosis

\begin{tabular}{lccc}
\hline \multicolumn{1}{c}{ Variables } & N & Skewness & Kurtosis \\
\hline Entrepreneurial Orientation (EO) & 350 & 0.077 & 0.260 \\
Organizational Performance (OP) & 350 & 0.095 & -0.164 \\
External Environment (EE) & 350 & -0.082 & 0.317 \\
\hline
\end{tabular}

Next, to ensure that the data are normally distributed is by checking the Normal Probability Plot (Normal Q-Q Plot). Figure 2 reports that it clearly showed that the data are normally distributed. Hence, it did not violate the assumption of normality. 


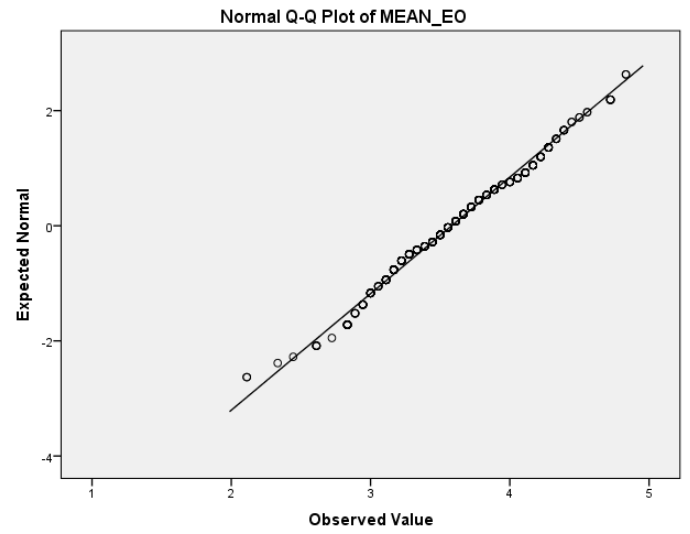

(a) Entrepreneurial Orientation (EO)

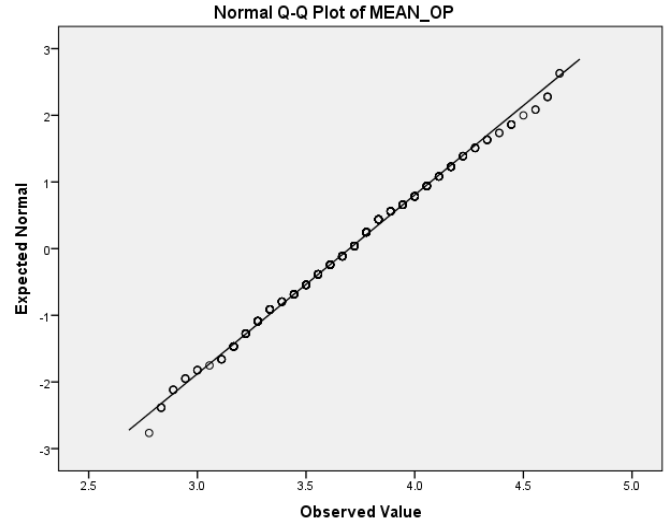

(b) Organisational Performance (OP)

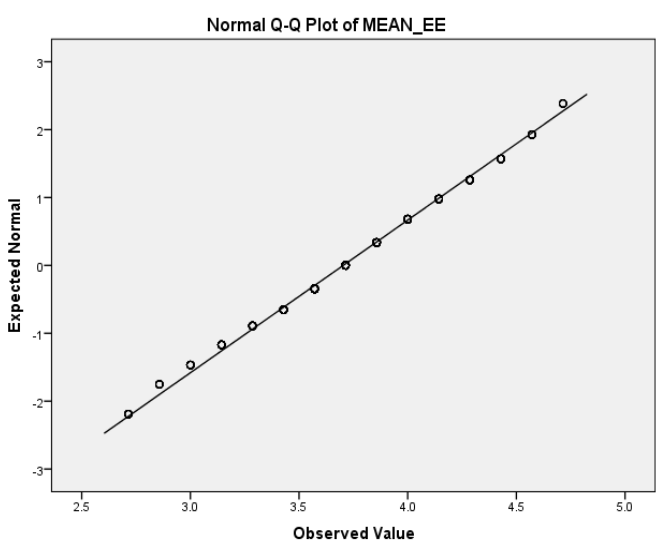

(c) External Environment (EE)

Figure 2: Normal Probability Plot (Normal Q-Q Plot)

\section{Linearity Assumptions}

Based on Figure 3, it demonstrated that the points lie in a reasonable straight diagonal line from bottom left to top right (Pallant, 2011). In this case, there is no major deviation from normality.

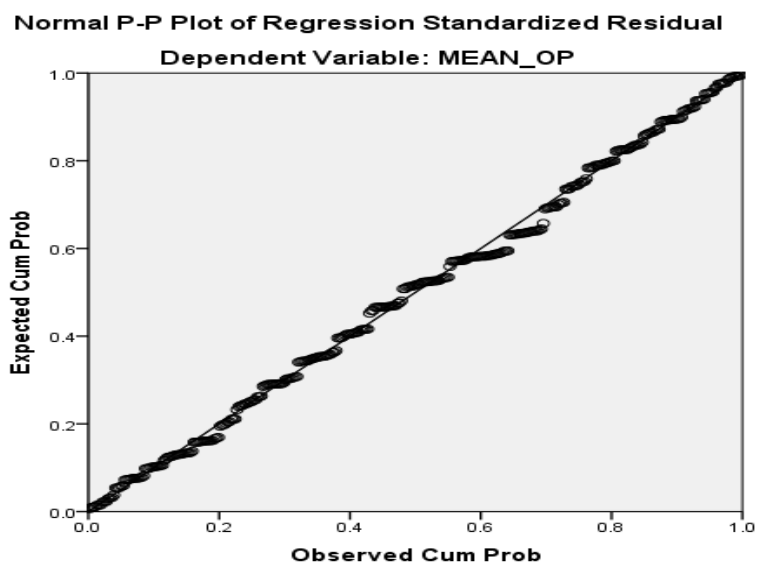

Figure 3: Scatter Plots of Entrepreneurial Orientation on Organization Performance 


\section{Respondent Demographics}

Table 3 shows the demographic information of 381 owner/founder of e-business for this study. Most of the respondents have Bachelor Degree and the year of their e-business establishment are between 1-10 years.

Table 3:Respondent profile

\begin{tabular}{llcc}
\hline \multirow{2}{*}{ Demographic Characteristics } & $\begin{array}{c}\text { Frequency } \\
(\boldsymbol{f})\end{array}$ & Percentage (\%) \\
\cline { 3 - 4 } Gender & Male & 139 & 39.7 \\
& Female & 211 & 60.3 \\
\hline Ethnic & Malay & 329 & 94.0 \\
& Chinese & 4 & 1.1 \\
& Indian & 14 & 4.0 \\
& Bumiputera & 3 & 0.9 \\
\hline Academic & SPM & 5 & 1.4 \\
Qualification & Diploma & 90 & 25.7 \\
& Bachelor Degree & 240 & 68.6 \\
& Master Degree & 15 & 4.3 \\
\hline Number of & $1-49$ & 313 & 89.4 \\
Employee & 50-59 & 37 & 10.6 \\
\hline Years of & $1-10$ years & 328 & 93.7 \\
Establishment & 10 years above & 22 & 6.3 \\
\hline
\end{tabular}

\section{Assessment of Measurement Model}

The PLS-SEM method and statistical software SmartPLS 3 (Ringle, Wende, and Becker, 2015) was used to estimate the hypothesized model. In this study, PLS-SEM was used for several reasons. First, the exploratory nature of the research (Richter et al., 2016) as the study was to investigate the relationship between entrepreneurial orientation, external environment and organizational performance. Second, the PLS-SEM can handle complex frameworks (Ramayah et al., 2018; Hair et al., 2017; Richter et al., 2016), and is recommended for the moderating model. Given the present research EE as a moderator, the PLS-SEM approach was suitable for the study.

In terms of analysis, Andersen and Gerbing (1988) stated that PLS-SEM is a two-step process involving assessment of the measurement and structural model (Memon, Salleh and Baharom, 2017). First, the measurement model was assessed by examining the internal consistency reliability, convergent validity (CV), and discriminant validity (DV) (Hair et al., 2017). Internal consistency reliability measures the degree to which the items measure the latent construct (Hair et al., 2006); it was assessed through composite reliability (CR) scores.

Table 4 depicts the assessment of factor loadings, composite reliability (CR) and average variance extracted (AVE) of this study. The composite reliability (CR) values of 0.934 (entrepreneurial orientation), 0.877 (organizational performance) and 0.874 (external environment) exceeded the recommended criterion of 0.7 (Avkiran, 2017; Nunnally, 1978), demonstrating high internal consistency or the appropriateness of the scales used in this study. Similarly, the variables in this study demonstrate good convergent validity. All the constructs achieve a minimum threshold value of 0.5 for average variance extracted (AVE) which is an 
indication that the items explain more than 50 per cent of the construct's variances (Hair et al., 2014).

Table 4: Factor Loadings, CR and AVE

\begin{tabular}{|c|c|c|c|c|}
\hline Construct & Item & Loading & $\mathrm{CR}$ & AVE \\
\hline Entrepreneurial & EO1 & 0.763 & 0.934 & 0.703 \\
\hline \multirow[t]{12}{*}{ Orientation } & $\mathrm{EO} 2$ & 0.730 & & \\
\hline & EO3 & 0.714 & & \\
\hline & EO4 & 0.800 & & \\
\hline & EO7 & 1.00 & & \\
\hline & EO9 & 0.870 & & \\
\hline & EO10 & 0.738 & & \\
\hline & EO11 & 0.800 & & \\
\hline & EO12 & 1.00 & & \\
\hline & EO15 & 0.840 & & \\
\hline & EO16 & 0.854 & & \\
\hline & EO17 & 0.794 & & \\
\hline & EO18 & 0.750 & & \\
\hline Organizational & NF1 & 0.846 & 0.877 & 0.641 \\
\hline \multirow[t]{7}{*}{ Performance } & NF2 & 0.833 & & \\
\hline & NF3 & 0.846 & & \\
\hline & NF4 & 0.915 & & \\
\hline & $\mathrm{F} 1$ & 0.805 & & \\
\hline & $\mathrm{F} 2$ & 0.765 & & \\
\hline & F3 & 0.770 & & \\
\hline & $\mathrm{F} 4$ & 0.753 & & \\
\hline External & EE1 & 0.774 & 0.874 & 0.637 \\
\hline \multirow{3}{*}{ Environment } & EE2 & 0.696 & & \\
\hline & EE3 & 0.785 & & \\
\hline & EE4 & 0.920 & & \\
\hline
\end{tabular}

Note: $\mathrm{CR}=$ composite reliability; $\mathrm{AVE}=$ average variance extracted

Next, factor loadings and average variance extracted (AVE) were assessed to determine the convergent validity of the constructs. Convergent validity is the "extent to which a measure correlates positively with alternative measures of the same construct" (Hair et al., 2017, p. 112). A factor loading should be 0.708 or higher, and, 0.7 considered close enough to be acceptable (Hair, Ringle, and Sarstedt, 2011). However, indicators with weaker factor loadings (i.e., 0.40 to 0.70 ) can be retained if other indicators possess high loadings, and overall construct should explain at least $50 \%$ variance (AVE $=0.50$ ) (Hair et al., 2017). In this study, the AVE scores for all constructs were all above 0.50 after the process of 3 items deletion (EO8, F5 and F6). As such, all the three construct meet the threshold where all CRs were above the 0.7 cut-off value and AVEs were above 0.5 cut-off values (Hair et al. 2014).

Discriminant validity is "the extent to which a construct is truly distinct from other constructs by empirical standards" (Hair et al., 2017). Henseler, Ringle, and Sarstedt (2015) suggested the Heterotrait-Monotrait ratio of correlations (HTMT) approach to determine the DV of the constructs. To achieve DV, the HTMT value should not be greater than the HTMT.85 value of 0.85 (Kline, 2015), or the HTMT.90 value of 0.90 (Gold, Malhotra, and Segars, 2001). As shown in Table 5, all values have passed both HTMT.85 and HTMT.90 measures (Gold et al., 
2001; Henseler et al., 2015; Kline, 2015), hence, discriminant validity has been ascertained. This indicates that, each construct in the model measures a unique subject and captures phenomena not presented by other constructs in the model.

Table 5: HTMT Criterion

\begin{tabular}{cccc}
\hline & EO & EE & OP \\
\hline EO & & 0.749 & \\
& & CI.90 & \\
EE & & $(0.635,0.841)$ & \\
OP & 0.103 & & \\
& CI.90 & 0.094 & \\
& $(0.133,0.214)$ & CI.90 & $(0.092,0.195)$ \\
\hline
\end{tabular}

Note: Criteria: discriminant validity is established at HTMT0.85

\section{Collinearity Assessment}

Before assessing the structural model, it is important to ensure that there are no collinearity issues in the structural model. According to Kock and Lynn (2012) although the criteria of discriminat validity are met, lateral collinearity issue may sometimes mislead the findings in a cautious way, because it can mask the strong causal effect in the model. This study included using variance inflation factors (VIF) to examine multicollinearity. A VIF value greater than 5 indicates multicollinearity (Hair et al., 2014). In this study, the VIF values were below than 5 (entrepreneurial orientation=1.660, external environment=1.672) indicating that the multicollinearity is not concerned in this study. Table 6 presents the outcome of the collinearity test.

Table 6: Collinearity assessment

\begin{tabular}{|c|c|c|}
\hline Construct & 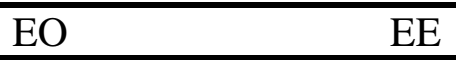 & $\mathrm{OP}$ \\
\hline $\mathrm{EO}$ & & 1.660 \\
\hline $\mathrm{EE}$ & & 1.672 \\
\hline
\end{tabular}

\section{Assessment of Structural Model}

After looking into measurement model, this section proceeds to the structural model assessment. Structural model was assessed to test the causal relationships between entrepreneurial orientation and organizational performance. To assess structural model, Hair et al., (2017) recommended looking at the coefficient of determination $\left(\mathrm{R}^{2}\right.$ value), path coefficient ( $\beta$ value) and the corresponding t-values via boostrapping procedure with 5,000 interaction to confirm statistical significance (Hair et al. 2014).

Table 7 illustrates the results of path coefficient assessment using the bootstrapping procedure for each of the hypothesized relationship in the model. The proposed relationships are significant whereby the relationships are found to have $t$-value $>1.645$, thus significant at 0.05 level of significant. Specifically, it can be seen that the EO $(\beta=0.322, t=5.283, L L=0.238$, 
$\mathrm{UL}=0.435$ ), this result explains that higher EO values are related to high organizational performance. Hence, it is surmised that EO have positive effect on organizational performance of e-business in Malaysia. As such, $H \mathrm{H}$ is supported.

Table 7: Hypothesis Testing

\begin{tabular}{clccc}
\hline Hypothesis & \multicolumn{1}{c}{ Relationship } & $\begin{array}{c}\text { Direct } \\
\text { Effect } \\
\end{array}$ & t-value & Decision \\
\hline $\mathrm{H} 1 \mathrm{~B})$ & $\begin{array}{l}\text { Entrepreneurial Orientation } \rightarrow \\
\text { Organizational Performance }\end{array}$ & 0.322 & $5.283^{* *}$ & Supported \\
& & & \\
\hline Note: $* \mathrm{p}<0.05 ; * * \mathrm{p}<0.01$ (one-tailed) & & &
\end{tabular}

Hair et al., (2017) also suggested that in addition to these basic measures (path coefficient) should also report the predictive relevance $\left(\mathrm{Q}^{2}\right)$ as well as the effect sizes $\left(\mathrm{f}^{2}\right)$ (Ramayah et al., 2017). To measure the effect size $\left(\mathrm{f}^{2}\right)$, Cohen (1988) guideline is used where the values of 0.02 , 0.15 and 0.35 represent small, medium and substantial effects respectively (Ramayah et al., 2016). The $\mathrm{f}^{2}$ value in Table 6 show substantial effect on entrepreneurial orientation towards organizational performance $\left(\mathrm{f}^{2}=0.548\right)$. In addition, the predictive relevance $\left(\mathrm{Q}^{2}\right)$ was examined using blindfolding procedure. Fornell and Cha (1994) and Hair et al., (2014), suggested that a $\mathrm{Q}^{2}$ value larger than 0 indicates that model has predictive relevance for a certain dependent construct. As shown in Table 8 , the $\mathrm{Q}^{2}$ value of 0.342 represent entrepreneurial orientation and organizational performance has sufficient predictive relevance.

Table 8 : Determination of Coefficient $\left(\mathbf{R}^{2}\right)$, Effect Size $\left(\mathbf{f}^{2}\right)$ and Predictive Relevance $\left(Q^{2}\right)$

\begin{tabular}{lcccc}
\hline \multicolumn{1}{c}{ Path } & $\begin{array}{c}\text { Coefficient of } \\
\text { determination }\left(\mathrm{R}^{2}\right)\end{array}$ & $\begin{array}{c}\text { Predictive } \\
\text { relevance } \\
\left(\mathrm{Q}^{2}\right)\end{array}$ & Effect size $\left(\mathrm{f}^{2}\right)$ \\
\hline $\begin{array}{l}\text { Entrepreneurial } \\
\text { Orientation }\end{array}$ & & & 0.548 & Substantial \\
$\begin{array}{l}\text { Organizational } \\
\text { Performance }\end{array}$ & 0.507 & 0.342 & & \\
\hline
\end{tabular}

\section{Assessment of Moderator Analysis}

To perform moderator analysis using interaction effect (moderator variable is continuos variable), external environment play a major role of moderator effect (reflective continuous variable) (Ramayah et al., 2018). In examining the interaction effects of moderator using PLSSEM, this study applied the orthogonalizing approach (Henseler \& Chin, 2010) in detecting the moderating effect of external environment on the relationship between entrepreneurial orientation and organizational performance. The orthogonalizing approach was preffered in this study is to minimizing estimation bias as it able to avoid multicollinearity issue (Henseler \& Chin, 2010). The significant effect of external environment was assessed by using a bootstrapping re-sampling with 5000 re-samples. Table 9 elucidates the moderating effect of external environment on the relationship between entrepreneurial orientation and organizational performance $(\beta=-0.273)$. The results from Table VII allow for a conclusion to 
be made where the effects of entrepreneurial orientation ( $t$-value $=0.750)$ on organizational performance were not significantly moderated by external environment, as the t-values below the critical value of 1.96 . As such, $H 2$ is rejected.

Table 9: Result of Moderating Effects of External Environment

\begin{tabular}{|c|c|c|c|c|c|}
\hline Hypotheses & Relationship & Standard $\beta$ & $\begin{array}{c}\text { SE } \\
\text { (STERR) }\end{array}$ & $\begin{array}{c}\text { t-value } \\
(|\mathrm{O} / \mathrm{STDEV}|)\end{array}$ & Decision \\
\hline $\mathrm{H} 5$ & $\mathrm{EO}^{*} \mathrm{EE} \rightarrow \mathrm{OP}$ & -0.273 & 0.364 & 0.750 & Not Supported \\
\hline
\end{tabular}

\section{Comon Method Bias}

A Harman's single factor test was performed (Podsakoff et al., 2003) to determine if there were any issues in relation to common method bias (Memon et al., 2017). The common method bias exists if one principal factor accounts for the majority of the total variance, i.e. more than $50 \%$ (Podsakoff et al., 2003). From the analysis, the first factor captured only 15.09 percent of the variance in the data. Therefore, it can be concluded that the common method bias did not exist in this study.

\section{Discussions and Conclusion}

In this study, EE reacts as moderator in the relationship between EO and organizational performance of e-business in Malaysia. The idea behind the moderation effect of EE on the relationship between EO and organizational performance of e-business in Malaysia tends to rely on how the unpredictable situation effect their EO and performance of e-business (Martins and Rialp, 2013). In addition, in terms of moderating variable, this research also gives the information on the importance of $\mathrm{EE}$ in enhancing EO and organizational performance. Given the previously held belief that EE plays an important role where the changes and unpredictability in the EE in which firms operate determines how they fit and their ensuing performance.

Surprisingly, the finding in this study reported that EE does not moderate the relationship between EO and organizational performance of e-business in Malaysia. The results of this study challenge the literature, which stipulates that there should be a significant moderating effect of EE on EO and organizational performance relationship (Mohd, 2005; Jabeen \& Mahmood, 2014). A possible explanation for these findings is that EE factors affect business activities and performance. In other words, business activities and performance are dependent on external environmental factors (Otache \& Mahmood, 2015).

In the present study, the findings dispel that EE would not be an effect on the relationship between EO and OP of e-business in Malaysia. A plausible reason may relate to different context in Malaysia. Most of the studies on the influence of EE towards EO and organizational performance were conducted outside of Malaysia such as studies by Aliyu et al., (2015); Jabeen \& Mahmood (2014); Aliyu \& Mahmood (2015). Different context variables can have different influences where the external environmental factors play an important role in business planning, decision-making and business performance (Otache \& Mahmood, 2015). It is possible that the differences may arise from the variation in the context of the study whereby in the Asian context of emerging countries, the EE does not emerge as a significant contributor 
as moderator to the development of EO and organizational performance. The result from this research can help organization (e-business) in determining and identifying the influence of EE in enhancing EO and organizational performance. Hence, e-business need to be proactive and nurture an enabling business performance that facilitates EO and EE among employees in order to be relevant and sustainable in today's competitive market.

This study concluded that entrepreneurial orientation and external environment are vital to promote organizational performance of e-business in Malaysia. These findings able to serve as a guideline for e-business owners or founders to improve their organizational performance thus compete in the digital sphere. It is also suggested that similar future study emphasizes in depth on the ability of entrepreneurial orientation and external environment capabilities in sustaining e- business performance towards business uncertainties.

\section{References}

Aliyu, S. M., \& Mahmood, R. (2015). The Moderating Role of Business Environment in the Relationship between Entrepreneurial Orientation and Business Performance among Nigerian SMEs. Jurnal Pengurusan, 43, 119-128.

Aliyu, S. M., Rogo, H. B., \& Mahmood, R. (2015). Knowledge Management, Entrepreneurial Orientation and Firm Performance: The Role of Organizational Culture. Asian Social Science, 11(23), 140-152.

Alkali, M., \& Isa, A. H. M. (2012). Assessing the Influence of External Environmental Factors, on the Performance of Small Business Manufacturing enterprises in Bauchi state, Nigeria. Interdisciplinary Journal of Contemporary Research In Business, 4(7), 621628.

Alegre, J. and Chiva, R. (2013). Linking Entrepreneurial Orientation and Firm Performance: The Role of Organizational Learning Capability and Innovation Performance. Journal of Small Business Management, 51(4), 491-507.

Al-Swidi, A.K. \& Mahmood, R. (2012). Total quality management, entrepreneurial orientation and organizational performance: The role of organizational culture. Journal of Business Management 6(13): 4717-4727.

Arbaugh, J.B., Cox, L.W. \& Camp, S.M. 2009. Is entrepreneurial orientation a global construct? A multi-country study of entrepreneurial orientation, growth strategy, and performance. The Journal of Business Inquiry 8(1): 12- 25.

Anderson, J. (2010). A critical examination of the EO -performance relationship. International Journal of Entrepreneurial Behavioral and Research, 16(4), 309- 329.

Andersen, J.C., and D.W. Gerbing. (1988) "Structural Equation Modelling in Practice. A Review and Recommended Two-Step Appraoch." Psychological Bulletin 103: 411-23.

Ambad, S.N.A. \& Abdul Wahab, K. (2013). Entrepreneurial orientation among large firms in Malaysia: Contingent effects of hostile environments. International Journal of Business and Social Science, 4(16): 96-107.

Ahmad, S. Z., Rani, A. N. S., \& Kassim, M. S. K. (2010). Business challenges and strategies for development of small-and medium-sized enterprises (SMEs) in Malaysia. International Journal of Business Competition and Growth, 1(2), 177-197.

Aliyu, M. S., \& Mahmood, R. (2015). The Moderating Role of Business Environment in the Relationship between Entrepreneurial Orientation and Business Performance among Nigerian SMEs. Jurnal Pengurusan, 43, 119-128.

Avkiran, Necmi Kemal. (2017) "An In-Depth Discussion and Illustration of Partial Least Squares Structural Equation Modeling in Health Care." Health Care Management Science: $1-8$. 
Basu, A. \& Muylle, S., (2007). How to Plan E-Business Initiatives in Established Companies. MIT Sloan Management Review, 49(1), pp. 28- 37.

Barney, J. (1991). Firm Resources and Sustained Competitive Advantage. Journal of Management, 17(1), 99-120.

Bolton, D. L., \& Lane, M. D. (2012). Individual entrepreneurial orientation: Development of a measurement instrument. Education+ Training, 54(2/3), 219-233.

Burns, A.C. and Bush, R.F. (2005), Marketing Research, Pearson Prentice-Hall, NJ.

Bryman, A. \& Bell, E. (2011). Business Research Methods. Oxford, NY, Oxford University Press.

Cohen, J. (1988). Statistical Power Analysis for the Behavioral Sciences. 2nd ed. New Jersey: Lawrence Erlbaum.

Covin, J. G., \& Slevin, D. P. (1991). A Conceptual Model of Entrepreneurship as Firm Behavior. Entrepreneurship: Theory \& Practice, 16(1), 7-25.

Covin, J.G. \& Miles, M.P. (1999). Corporate entrepreneurship and the pursuit of competitive advantage. Entrepreneurship: Theory and Practice 23(3): 47-47.

Covin, J. G., \& Lumpkin, G. T. (2011). Entrepreneurial Orientation Theory and Research: Reflections on a Needed Construct. Entrepreneurship Theory \& Practice, 35(5), 855872.

Covin, J. G., \& Slevin, D. P. (1989). Strategic Management of Small Firms in Hostile and Benign Environment. Strategic Management Journal, 10(1), 75-87.

Chang, S.J., van Witteloostuijn, A. and Eden, L. (2010), "From the editors: common method variance in international business research", Journal of International Business Studies, Vol. 41 No. 2, pp. 178-184.

Chang, J., \& Dasgupta, B. (2015). An Investigation of the Barriers to E-business Implementation in Small and Medium-Sized Enterprises. International Journal of Social, Behavioral, Educational, Economic, Business and Industrial Engineering, 9(1), 26-36.

Dess, G. G., Lumpkin, G. T., \& Covin, J. G. (1997). Entrepreneurial Strategy Making and Firm Performance : Tests of Con. Strategic Management Journal, 18(6), 677-695.

Deepababu, K. G., \& Manalel, J. (2016). Entrepreneurial Orientation And Firm Performance: A Critical Examination. IOSR Journal of Buiness and Management, 18(4), 21-28.

Fairoz, F.M., Hirobumi, T., and Tanaka, T. (2010). Entrepreneurial Orientation and Business Performance of Small and Medium Scale Enterprises of Hambantota District Sri Lanka. Asian Social Science, 6(3), 34-46.

Gold, A.H., A. Malhotra, and A.H. Segars. (2001). "Knowledge Management: An Organizational Capabilities Perspective." Journal of Management Information Systems, 18, no. 1: $185-214$.

Hair, J. F., Hult, G. T. M., Ringle, C., \& Sarstedt, M. (2014). A Primer On Partial Least Squares Structural Equation Modeling (PLS-SEM). Thousand Oaks, CA: SAGE Publications, Incorporated.

Hair, Joseph F., G.T.M. Hult, C.M. Ringle, and M. Sarstedt. (2017). A Primer on Partial Least Squares Structural Equation Modeling (PLS-SEM). 2nd ed. Thousand Oaks, CA: Sage.

Hair, Joseph F., W.C. Black, B.J. Babin, R.E. Anderson, and R.L. Tatham. (2006). Multivariate Data Analysis. 6th ed. New Jersey: Prentice Hall.

Hair, Joseph F., Christian M. Ringle, and Marko Sarstedt. (2011). "PLS-SEM: Indeed a Silver Bullet." Journal of Marketing Theory and Practice, 19, no. 2: 139-51.

Hakala, H. (2013). Entrepreneurial and learning orientation: effects on growth and profitability in the software sector. Baltic Journal of Management, 8(1), 102-118. 
Henseler, J., Ringle, C.M. and Sinkovics, R.R. (2009), "The use of partial least squares path modeling in international marketing", Advances in International Marketing, Vol. 20 No. 1, pp. 277-319.

Henseler, J., \& Chin, W. W. (2010), A comparison approaches or the analysis of interaction effects between latent variables using partial least squares path modeling. Structural Equation Modeling, 17(1), 82-109.

Henseler, J., Ringle, C.M. and Sarstedt, M. (2015), "A new criterion for assessing discriminant validity", Journal of the Academy of Marketing Science, Vol. 43 No. 1, pp. 115-135.

Herath, H.M.A. \& Mahmood, R. (2013). Strategic orientation based research model of SME performance for developing countries. Review of Integrative Business and Economics Research 2(1), 430-440.

Idar, R., \& Mahmood, R. (2011). Entrepreneurial orientation and market orientation relationship Performance: the SME perspective. Interdisciplinary Review of Economics and Management, 1(2), 1-8.

Jabeen, R., Aliyu, S. M., \& Mahmood, R. (2016). The Moderating Effect of External Environment on the Relationship Between Market Orientation and Business Performance: a Quantitaitve Approach. Ipbj, 8(1), 16-25.

Jabeen, R., \& Mahmood, R. (2014). Effect of External Environment on Entrepreneurial Orientation and Business Performance Relationship. Social and Basic Sciences Research Review, 2(9), 394-403.

Khamis, N., Sulaiman, A., \& Mohezar, S. (2014). Achieving e-Business Excellence through Knowledge Management and Organizational Learning Capabilities: A Malaysian Perspective. International Journal of Economics and Management, 8(2), 343-364.

Kock, N., \& Lynn, G.S. (2012). Lateral Collinearity and Misleading Results in Variance-Based SEM: An Illustration and Recommendations. Journal of the Association for Information Systems, 13(7), 546-580.

Krejcie, R. V., \& Morgan, D. W. (1970). Determining sample size for research activities. Educational and Psychological Measurement, 30, 607-610.

Kline, R.B. (2015). Principles and practice of structural equation modeling. Guilford publications.

Lee, C., Lee, K., \& Pennings, J. M. (2001). Internal capabilities, external networks, and performance: a study on technology-based ventures. Strategic management journal, 22(6-7), 615-640.

Lumpkin, G. T., Cogliser, C. C., \& Schneider, D. R. (2009). Understanding and measuring autonomy: An entrepreneurial orientation perspective. Entrepreneurship: Theory and Practice, 33(1), 47-69.

Lumpkin, G. T., \& Dess, G. G. (2001). Linking two dimensions of entrepreneurial orientation to firm performance: The moderating role of environment and industry life cycle. Journal of Business Venturing, 16(5), 429-451.

Lumpkin, G. T., \& Dess, G. G. (1996). Clarifying the Entrepreneurial Orientation Construct and Linking It to Performance. Academy of Management Review, 21(1), 135-172.

Lo, M. C., Wang, Y. C., Wah, C. R. J., \& Ramayah, T. (2016). The critical success factors for organizational performance of SMEs in Malaysia: a partial least squares approach. Review of Business Management, 18(61), 370-391.

Martins, I., \& Rialp, A. (2013). Entrepreneurial orientation, environmental hostility and SME profitability: a contingency approach. Cuadernos De Gestión, 13(2), 67-88.

Madhoushi, M., Sadati, A., \& Delavari, H. (2011). Entrepreneurial Orientation and Innovation Performance : The Mediating Role of Knowledge Management. Asian Journal of Business Management, 3(4), 310-316. 
Memon, M. A., Salleh, R., \& Baharom, N. R. (2017). The Mediating Role of Work Engagement Between Pay Satisfaction and Turnover. International Journal of Economics, Management and Accounting, 25(1), 43-69.

Mohd, K. H. (2005). Small and Medium-Sized enterprises in Malaysia-Role in Issues. Sintok: UUM Press.

Murgor Paul Kimutai. (2014). External Environment, Firm Capabilities, Strategic Responses And Performance Of Large Scale Manufacturing Firms In Kenya. PhD Thesis, University of Nairobi, Kenya.

Naman, J. L., \& Slevin, D. P. (1993). Entrepreneurship and the Concept of Fit: A Model and Empirical Tests. Strategic Management Journal, 14(2), 137-153.

Nunnally, J.C. (1978). Psychometric Theory. New York, NY: McGraw-Hill.

Otache, I., \& Mahmood, R. (2015). Corporate Entrepreneurship and Business Performance: The Role of External Environment and Organizational Culture: A Proposed Framework. Mediterranean Journal of Social Sciences, 6(4), 524-531.

Podsakof, Philip M., S. MacKenzie, J. Lee, and Nathan P. Podsakoff. (2003). Common Method Biases in Behavioural Research." MIS Quarterly 30, no. 1: 115-41.

Ramayah, T., Jacky Cheah, Francis Chuah, Hiram Ting, and Mumtaz Ali Memon. (2018). Partial Least Squares Structural Equation Modeling (PLS-SEM) Using SmartPLS 3.0: An Updated Guide and Practical Guide to Statistical Analysis. Kuala Lumpur, Malaysia: Pearson.

Ramayah, T., Yeap, J. A. L., Ahmad, N. H., Halim, H. A., \& Rahman, S. A. (2017).Testing a Confirmatory model of Facebook Usage in SmartPLS using Consistent PLS. International Journal of Business and Innovation, 3(2), 1-14.

Ramayah, T., Cheah, J., Chuah, F., Ting, H., \& Memon, M. A (2016). Partial Least Squares Structural Equation Modeling(PLS-SEM) using SmartPLS 3.0 (1st ed.). Kuala Lumpur, Malaysia: Pearson.

Ringle, C.M., Wende, S. and Becker, J.M. (2015), "SmartPLS 3.Boenningstedt: SmartPLS GmbH", available at www.smartpls.com (accessed 10 October 2016).

Richter, Nicole Franziska, Rudolf R. Sinkovics, Christian M. Ringle, and Christopher Schlägel. (2016). A Critical Look at the Use of SEM in International Business Research. International Marketing Review 33(3): 376-404.

Rauch, A., Wiklund, J., Lumpkin, G. T., \& Frese, M. (2009). Entrepreneurial orientation and business performance: An assessment of past research and suggestions for the future. Entrepreneurship Theory and Practice, 33(3), 761-787.

Runyan, R., Droge, C. \& Swinney, J. (2008). Entrepreneurial orientation versus small business orientation: What are their relationship? Journal of Small Business Management 46(4): 567-588.

Thoo Ai Chin (2014). Supply Chain Integration And Operational Capability Effects on Performance in Malaysian Small and Medium Enterprises. Universiti Teknologi Malaysia.

Wang, D. H., \& Huynh, Q. L. (2013). Mediating Role of Knowledge Management in Effect of Management Accounting Practices on Firm Performance. Journal of Knowledge Management, Economics and Information Technology, 3(3), 1-25.

Wiklund, J. (1999). The Sustainability of the Entrepreneurial Orientation-Performance Relationship. Entrepreneurship Theory and Practice, 24(1), 37-48.

Wiklund, J., \& Shepherd, D. (2003). Knowledge-based resources, entrepreneurial orientation, and the performance of small and medium- sized businesses. Strategic Management Journal, 24(13), 1307-1314. 
Wiklund, J., \& Shepherd, D. (2005). Entrepreneurial orientation and small business performance: A configurational approach. Journal of Business Venturing, 20(1), 7191.

Zahra, S. A., \& Covin, J. G. (1995). Contextual influences on the corporate entrepreneurshipperformance relationship: A longitudinal analysis. Journal of Business Venturing, $10(1), 43-58$. 